\title{
$11 q$ deletion in neuroblastoma: a review of biological and clinical implications
}

\author{
Vid Mlakar ${ }^{1}$, Simona Jurkovic Mlakar ${ }^{1}$, Gonzalo Lopez ${ }^{3}$, John M. Maris ${ }^{3,4}$, Marc Ansari ${ }^{1,2}$ \\ and Fabienne Gumy-Pause ${ }^{1,2^{*}}$
}

\begin{abstract}
Deletion of the long arm of chromosome 11 (11q deletion) is one of the most frequent events that occur during the development of aggressive neuroblastoma. Clinically, 11q deletion is associated with higher disease stage and decreased survival probability. During the last 25 years, extensive efforts have been invested to identify the precise frequency of $11 \mathrm{q}$ aberrations in neuroblastoma, the recurrently involved genes, and to understand the molecular mechanisms of $11 \mathrm{q}$ deletion, but definitive answers are still unclear. In this review, it is our intent to compile and review the evidence acquired to date on 11q deletion in neuroblastoma.
\end{abstract}

Keywords: Neuroblastoma, 11q deletion, MYCN amplification, Cancer, Development, Metastasis, Review

\section{Background}

Neuroblastoma (NB) is the most frequent extracranial solid tumour in children, accounting for 7 to $8 \%$ of all childhood malignancies and $15 \%$ of all cancer-related deaths in this population. It is the most frequently diagnosed cancer during infancy, the median age at diagnosis being about 19 months. While $90 \%$ of the patients are younger than 5 years, NB is very rare after the age of 10 . NB originates from embryonal sympathoadrenal lineage of the neural crest and can arise anywhere along the sympathetic nervous system chain, with the majority of tumours occurring in the abdomen (65\%), more particularly in the adrenal gland. The other common sites involved are chest, neck and pelvis. Regional lymph nodes, bone marrow, bone, liver and subcutaneous tissue are the most frequently observed metastatic localizations $[1,2]$.

NB is a complex and heterogeneous disease, with a marked variability in prognosis depending of the age, stage and biological characteristics at diagnosis. The clinical course ranges from spontaneous regression to inexorable progression and death despite multimodal treatments. NB differentiation into benign ganglioneuroma is not uncommon and known for a long time. While NB maturation occurs spontaneously or after

\footnotetext{
* Correspondence: fabienne.gumypause@hcuge.ch

${ }^{1}$ CANSEARCH Research Laboratory, Geneva University Medical School,

Avenue de la Roseraie 64, 1205 Geneva, Switzerland

${ }^{2}$ Department of Pediatrics, Onco-Hematology Unit, Geneva University

Hospitals, Rue Willy-Donzé 6, 1205 Geneva, Switzerland

Full list of author information is available at the end of the article
}

chemotherapeutic treatments, multiple chemical modifiers were shown to suppress tumorigenicity and to induce NB differentiation in cell lines [3, 4].

Metastatic disease is present in approximately $50 \%$ of cases. Other biological factors associated with poor prognosis are: age at onset of more than 18 month at diagnosis, unfavourable histology, diploid DNA contents, MYCN amplification (MNA), and specific segmental chromosomal aberrations (SCA) such as $11 \mathrm{q}$ deletion, $1 \mathrm{p}$ deletion and $17 \mathrm{q}$ gain $[1,5,6]$. In contrast, an excellent overall (OS) and event-free survival in NBs with only numerical chromosome alterations is reported [7, 8]. In 2009, the International Neuroblastoma Risk Group Task Force published a classification system in order to stratify patients in different subgroups regarding the risk of death [9]. Recently, Matthay et al. proposed a modified version of this system taking into account the most recent genomic data and treatment approaches. Using clinical staging, image-defined risk factors for surgery, age at diagnosis, histology, tumour differentiation, $M Y C N$ status, genomic profile and ploidy, it is possible to stratify patients into four subgroups regarding the risk of death (very low, low, intermediate and high-risk). Whereas children in the very low-risk subgroup have an expected OS rate of $99-100 \%$, patients in the highrisk subgroup have a rate of long-term survival of less than $50 \%$ despite dose-intensive, multimodal therapy including surgery, high dose chemotherapy with autologous bone marrow transplantation, radiotherapy and immunotherapy [10]. In regard to this poor 
outcome, it is obvious that new therapeutic strategies are required to improve the outcome and decrease the toxicity (for a more general review of Neuroblastoma authors recommend the recent review of Matthay et al.) [10].

For more than two decades, 11q deletion is known to be a recurrent genetic alteration and suspected to contain NB suppressor gene(s) [11-13]. While 11q deletion is more frequently detected than MNA (35-45\% vs. 20$25 \%$, respectively), both alterations are almost mutually exclusive [1, 5, 14-17]. Interestingly, 70 to $80 \%$ of stage 4 NBs have MNA or 11q deletion [18-20] and the poor prognosis significance of $11 \mathrm{q}$ deletion approaches that of MNA [5]. In this article, we will review the data concerning $11 \mathrm{q}$ deletion in order to have a deeper understanding of its role in the development and/or progression of NB. In addition, the signature of 11q-deleted genes will be analyzed using QIAGEN's Ingenuity Pathway Analysis software (IPA, QIAGEN Redwood City) in order to understand potentially affected cellular processes and to position them in frequently dis-regulated networks of MYCN, MAPK and TP53 pathways.

\section{Clinical implication of $11 \mathrm{q}$ aberrations in neuroblastoma}

$11 \mathrm{q}$ aberration is reported in 20 to $45 \%$ of NBs depending on the genetic alterations analysed and the screening method used [5, 15-17, 21-23]. While 11q23 is the most frequent $11 \mathrm{q}$ region found to be deleted, different studies screened allelic status of chromosome $11 \mathrm{q}$ using microsatellite markers $[15,21]$ and found $11 \mathrm{q}$ loss of heterozygosity $(\mathrm{LOH})$ in approximately 34 to $44 \%$ of the NB samples. Nevertheless, a subgroup of these patients presented an unbalanced $11 \mathrm{qLOH}$ (unb11qLOH) defined as $\mathrm{LOH}$ at markers on $11 \mathrm{q}$ with retention of $11 \mathrm{p}$ material. Attieh et al. reported unb11qLOH in $17 \%$ of the whole NB group representing $50 \%$ of the $\mathrm{LOH}$ $11 \mathrm{q} 23 \mathrm{NB}$, a proportion that increased with clinical risk. In this study, 11q23 LOH and unb11qLOH were both associated with high-risk features, but only unb11qLOH was independently associated with a decreased 3-year EFS (50\% vs. 74\%) [21]. These results confirmed previous published data, which have all suggested an association between LOH at 11q23, and high-risk NB features at stage 4 and unfavourable histology [11, 15, 17, 24-26].

Similar results were found by using fluorescence in situ hybridization (FISH). Spitz et al. reported 11q23 alterations in $26 \%$ of the 611 NB samples analysed with $18 \%$ displaying a deletion resulting in monosomy of distal $11 \mathrm{q}$ and $8 \%$ showing an imbalance with at least two intact copies of $11 \mathrm{q} 23$ with additional centromere copies. Interestingly, it was shown that the proportion of $11 \mathrm{q}$ alterations increased with stage ( $8 \%$ in stage $1,10 \%$ in stage $2,11 \%$ in stage $4 S, 21 \%$ in stage 3 and $52 \%$ in stage 4) but also with age at diagnosis, proportion of $11 \mathrm{q}$ alteration increasing to more than $50 \%$ after the age of
2.5 years. As in other studies, 11q status was found prognostic for EFS and strongly correlated with occurrence of metastatic relapse [21, 27].

More recently, whole genome screening methods such as single nucleotide polymorphism (SNP) arrays and array based comparative genomic hybridization $(\mathrm{CGH})$ have been used to detect large genomic gains or losses. High-resolution arrays were also able to detect recurrent small, interstitial, genomic alterations, possibly involved in the development of NB. While whole (or numerical) chromosome changes without segmental alterations (NCA) [8] are frequently observed in low risk NBs with good outcome, SCA defined by gains or losses of partial chromosome material are associated with poor prognosis in most cases [7, 8, 28, 29]. With losses of $1 p, 3 p, 4 p$ and gains of $1 \mathrm{q}, 2 \mathrm{p}$ and $17 \mathrm{q} ; 11 \mathrm{q}$ loss is one of the most frequent SCA observed, reported in 13 to $68 \%$ of the samples depending of the cohort analysed [5, 7, 8, 28, 30, 31]. As previously reported, $11 \mathrm{q}$ loss was more frequently found in NBs with high-risk (HR) features (47 to $68 \%$ of the HR vs. 47 to $50 \%$ for MNA) [30, 31], and regularly found associated with poor prognosis [5, 7, 8, 29, 32]. Schleiermacher et al. reported that in $147 \mathrm{NBs}$ without MNA, a SCA profile was the strongest independent prognosis factor. In this cohort, $76 \%$ of NBs with SCAs showed an $11 \mathrm{q}$ deletion [8].

Interestingly, in the cohort studied by Caren et al., the median age at diagnosis was significantly higher in the $11 \mathrm{q}$ deletion group compared to NCA, MNA and $17 \mathrm{q}$ gain groups (42 months vs 3, 21 and 21 months, respectively). While the prognosis were similarly poor in MNA and $11 \mathrm{q}$ deletion groups (8 years OS $\sim 35 \%$ ), the median survival time after diagnosis was longer in $11 \mathrm{q}$ deleted NBs compared to MNA NBs (40 vs 16 months) [5]. Similar results concerning the age were recently reported in the Swedish cohort of unfavourable NBs where the median age at diagnosis was 58.5 months in NBs with 11q deletion vs 18 months in the MNA group [30]. While 11q alteration is detected mostly in older patients, over 18 months of age at diagnosis [31], recent analysis of the INRG database showed that in the youngest patients ( $<18$ months) with stage $3 \mathrm{NB}, 11 \mathrm{q}$ deletion is the only factor found independently associated with poor EFS and OS [32].

Different studies, which analysed correlations between $11 \mathrm{q}$ deletion and other genetic abnormalities, reported not only an anti-correlation with MNA, but also a positive association with $17 q$ gain and loss of $3 p$ [5, 8, 16, 17, 31, 33]. More recently, 11q loss was found positively correlated with $4 \mathrm{p}$ loss and $7 \mathrm{q}$ gain but not with $17 \mathrm{q}$ gain [14]. Usually recognized as mutually exclusive, MNA and 11q deletion tumours were rarely reported [5, 15, 22, 27, 31, 34-36]. In these infrequent cases, the prognosis seems to be highly dramatic $[27,34,35]$. The clinical significance 
of intra-tumour heterogeneity of MNA (hetMNA) defined by the coexistence of MNA cells as well as nonMNA cells detected by FISH in the same tumour, was recently studied by Bogen et al. [34]. In older patient (> 18 months), tumours were mostly found di- or tetra-ploid containing lower number of MNA cells but higher number of SCA, including 11q deletion (4/10), and chromosomal breakpoints. Clinically, these patients often present an aggressive disease with tumour progression and relapse [34].

In the particular subgroup of NBs occurring in adolescent and young adults [30], representing less than $5 \%$ of NBs and characterized by a high prevalence of SCA (35-85\%) and very low incidence of MNA, the prevalence of $11 \mathrm{q}$ loss is high, ranging between 30 to $60 \%$ [37-39]. In this particular subgroup where $A L K$ and $A T R X$ alterations are also more frequent and the outcome very poor [37-40], ATRX mutated NBs showed a higher number of SCA including 11q deletions (Fig. 1) [37].

In 2010, Schleiermacher et al., reported genomic profiling of paired tumour samples obtained at the time of diagnosis and relapse from 17 patients with NBs. In 4 cases, 11q loss was found as an additional segmental change only present in the relapse sample. Interestingly, 2 of these 4 patients were only treated by surgery at diagnosis, suggesting that these alterations were not directly linked to the effects of the chemotherapy or irradiation. Despite many efforts, it was not possible to determine if the 11q loss observed at relapse occurred secondarily during tumour progression conferring a selective advantage to the tumour cells or was already present in a sub-clone at diagnosis [41]. More recently, a relapse-specific 11q loss was detected in 3 out of $23 \mathrm{NB}$ samples by Eleveld et al., while this specific alteration was not found in 16 paired samples by Schramm et al. [42, 43].

It is now well recognized that $11 \mathrm{q}$ deleted NBs constitute a distinct subgroup of aggressive malignancies, but with distinct features compared to the $\mathrm{MYC}(\mathrm{N})$-driven subset [5]. A high frequency of chromosomal breaks suggestive of a chromosomal instability [3] is one of the main features of 11q deleted NBs, reported by different groups $[5,30]$. This finding suggests that one or more genes located on 11q could be involved in the chromosomal instability (CIN) phenotype, by haplo-insufficiency or by inactivation of the second allele by mutation or epigenetic modification. To address this point studies of clonal evolution on NB with 11q deletion are needed.

\section{1q chromosomal deletion mapping studies}

Since the first recognition that 11q deletion is an important event, many studies have focused on identifying the smallest region of overlap (SRO) aiming to pinpoint the location of the gene(s) responsible for the change in cell behaviour. The main conclusion from early studies by Guo et al., Maris et al. and Schleiermacher et al. (combining in total $183 \mathrm{NBs}$ ) was that the majority of NBs with 11q loss have large chromosomal deletions roughly ranging from 11q14.1 to the 11qter [8,11, 15]. The shortest

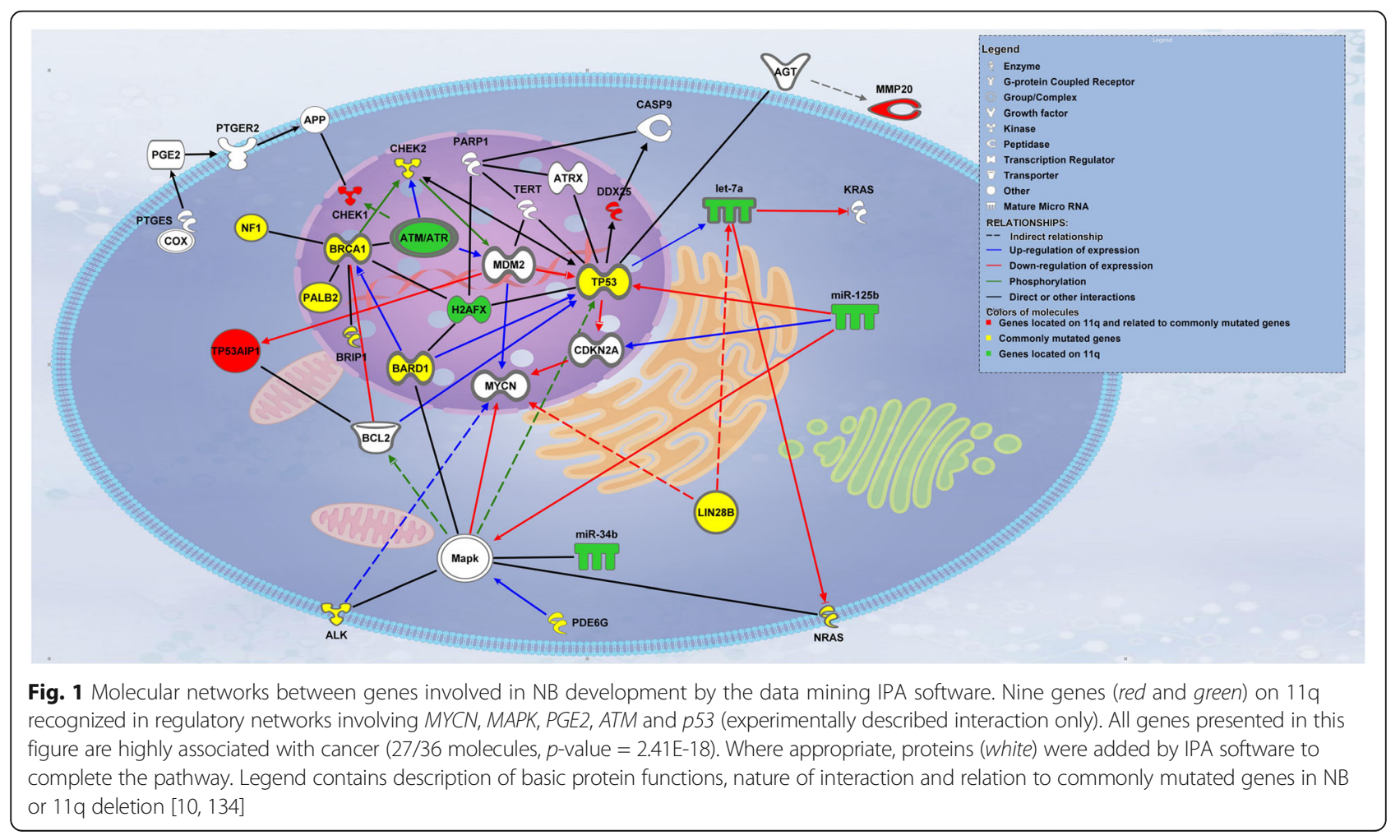


deletion was reported by Schleiermacher et al. that spanned from 11q23.1 to 11qter [8]. Both Maris and Guo reported the shortest region from 11q21 to 11qter. In addition, $12 \mathrm{NB}$ patients were found with intact 11qter having interstitial 11q deletion. Out of these 12 samples, 7 retained only a minor part of 11qter close to microsatellite marker D11S968 and for the remaining 5 cases, the SRO was proposed between D11S1340 (11q23.3) and D11S1299 (11q23.3) [15]. Later, after acknowledging the small number of samples used for determining the SRO, a broader SRO between D11S1358 (11q14.3) and D11S1345 (11q24.1) was proposed (Fig. 2a) [11]. More recently, segmentation data from SNP arrays obtained from the TARGET data matrix (https://target-data.nci.nih.gov/ Public/NBL/copy_number_array/L3/) highlight the differences between non-MNA and MNA SCA profiles (Fig. 2b and $\mathrm{c}$ respectively) and spotlight a breakpoint rich region at $11 \mathrm{q} 13$.

Further evidence for localizing the SRO came from precise identification of constitutional 11q deletions in NB patients. A few cases of germline hemizygous partial deletion of $11 \mathrm{q}$ associated with $\mathrm{NB}$ were reported in the literature (11q23 [44]; 11q14-q22 [45]; 11q14-23 [46, 47] and 11q14.1-23.3 [48]) and seem to support the broader SRO. Interestingly, in one of these cases, the NB was multifocal [45] and in another case the NB was associated with a ganglioneuroma (GN) [47]. Using the European Cytogeneticist Association Register of Unbalanced Chromosome Aberrations database (ECARUCA database http:// umcecaruca01.extern.umcn.nl:8080/ecaruca/ecaruca.jsp, date of analysis: 15.7.2016), we reviewed 132 cases with any kind of deletion between 11q14 and 11qter but no cases of NB were found. The most common abnormalities in these children were mental retardation and cranio-facial abnormalities. $11 \mathrm{q}$ deletions ranging from $11 \mathrm{q} 24$ or $11 \mathrm{q} 25$ to $11 \mathrm{qter}$ resulted in Jacobsen syndrome (OMIM 147791) but these patients did not develop NB. These data point to the conclusion that $11 \mathrm{q}$ deletions apparently do not have a high penetrance for NB and are not sufficient to cause it, but must be apparently accompanied by other genetic events. Additional support of such a conclusion came from early chromosomal transfer experiments carried out by Bader et al. showing that genes on $11 \mathrm{q} 25$ are only responsible
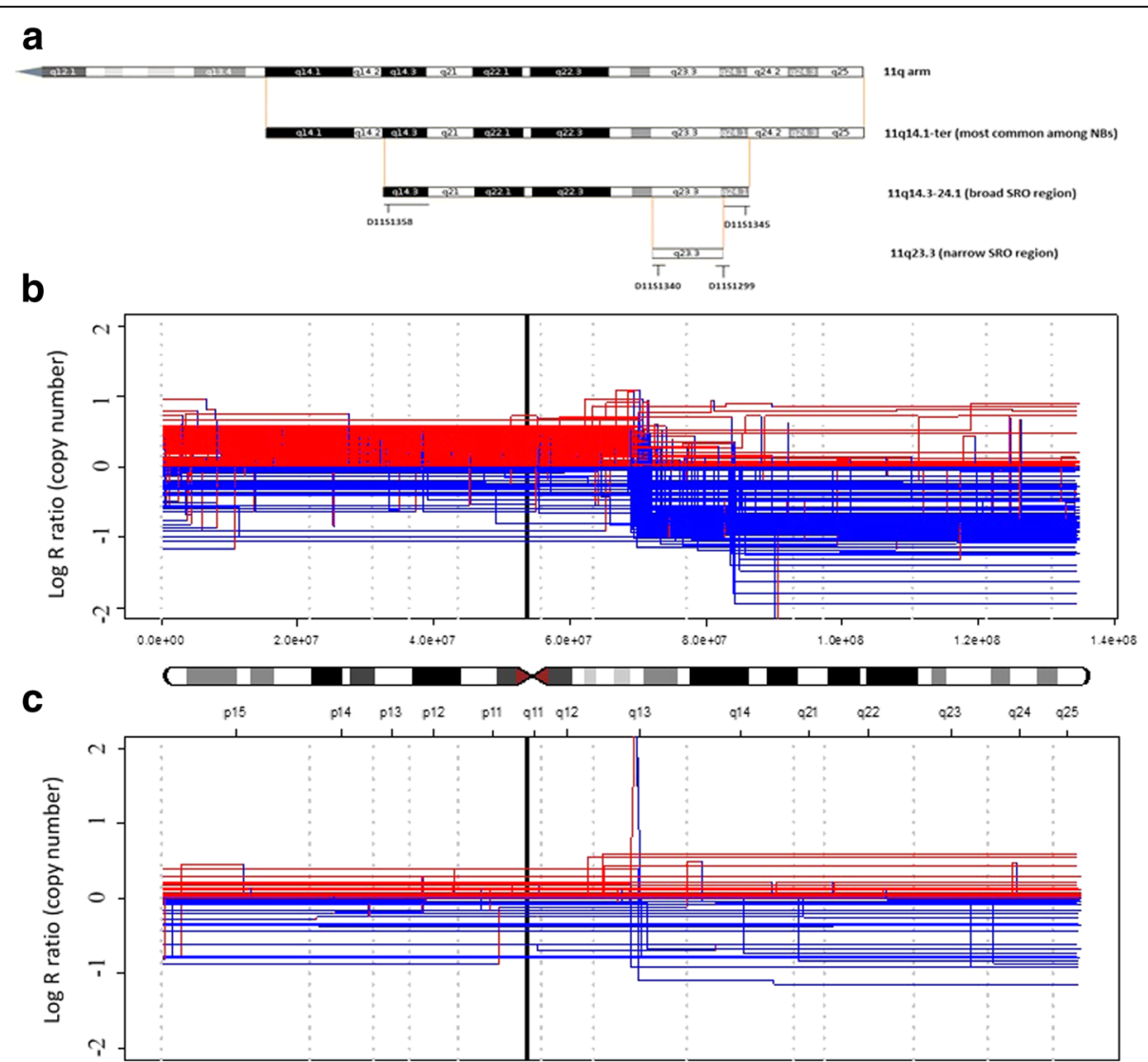

Fig. 2 Location of deletions on 11q arm in NB tumors. a Location of deletions on 11q arm in NB tumors. b Copy number segmentation plot of chromosome 11 of 214 non-MNA high-risk tumors; horizontal lines represent single tumor dosages represented as the base 2 logarithm (y axis) of the copy number along the chromosome; vertical lines indicate breakpoints associated with gain (red) and loss (blue) of genomic regions. c Analogously to $\mathbf{b}$, segmentation plot of chromosome 11 in 103 MNA tumors 
for NB differentiation but not of proliferation capability of tumour cell lines [49].

\section{Functional studies and sequencing of genes at $11 \mathrm{q}$}

Based on the knowledge described above, different groups have used functional testing of candidate genes to try to identify the gene(s) responsible for driving the tumourigenesis. Several candidates such as CADM1 (11q23.3, also known as TSLC1 or IGSF4) [50-52], ATM (11q22.3) [53] and H2AFX (11q23.3) [5] were probed by different groups (Fig. 1). Analysis of these genes for additional alteration(s), to satisfy Knudson's two hit hypothesis, showed no second mutation or hyper-methylation for CADM1 [50-52], ATM [53] and H2AFX (personal unpublished data). Although clear functionality (CADM1 and $A T M)$ and associations (CADM1, ATM, H2AFX) of these genes were established, their relevance to the development of $\mathrm{NB}$ in vivo remains under question given the lack of mechanism of their complete inactivation. Recently, our lab explored the possibility that 11q could be a substitute for direct amplification of $M Y C N$ by upregulating its expression. Results obtained on ATM knock down NB cell lines showed that $M Y C N$ upregulation was inconsistently found, and when detected, it was not as strong as in the case of $M Y C N$ amplification, nor was the molecular profile similar [53]. Another reason against such hypothesis is that MNA NBs and 11q-deleted NBs appear to be 2 different molecular entities as demonstrated by mRNA expression profiling $[22,23,54]$ and they appear to be mutually exclusive [11]. The reason for the latter is not yet fully understood, but it is interesting that a higher frequency of chromosomal breaks are observed in such tumours [36] perhaps pointing to the possibility of unsustainable chromosomal instability.

An additional interesting candidate frequently located near the 11q deletion breakpoints (11q13.4) is PHOX2A [55], a transcription factor involved in the maintenance of noradrenergic neuronal differentiation in the locus coeruleus during embryogenesis [56]. This gene is under transcriptional regulation by its homolog $P H O X 2 B$ $(4 \mathrm{p} 13)[57,58]$, one of the gene involved in the majority of the familial NB cases and known to be a master regulator of neural crest development [59-61]. After extensive search, no mutations in $P H O X 2 A$ were found but authors reported lower expression of this gene in unfavourable NB [55]. Unfortunately, $P H O X 2 A$ was not screened for hyper-methylation or small deletions for exploring other possibilities of gene inactivation.

$S D H D$ (11q23.1) is a well-known tumour-suppressor gene frequently mutated in familial paraganglioma and pheochromocytoma. Both tumours derive from the sympathetic nervous system, providing dePreter et al. with a good reason for exploring the possibility that $S D H D$ is the target of 11q loss. Upon detailed analysis of $31 \mathrm{NB}$ cell lines and $67 \mathrm{NB}$ tumours, two point mutations (frame shift and missense) were found in NB cell lines but no hyper-methylation or homozygous deletions were detected. SDHD mRNA expression was significantly reduced in NBs with 11q loss but functional analysis did not point to its influence on NB phenotype, prompting the group to conclude that $S D H D$ is probably of lesser significance to NB development [62].

Santo et al. hypothesized that microdeletions, fusions and rearrangements of 11q23 could be involved in dysregulation of important genes. By combining SNP arrays with comparative genomic hybridization and gene expression data, they were able to identify overexpression of FOXR1 (11q23.3) due to micro rearrangements in 3 out of $362 \mathrm{NB}$ cases. Additional functional studies showed that over-expression of this gene could functionally replace $M Y C N$ and drive proliferation of JoMa1 cells, while repression of FOXR1 by RNAi in HOS cells strongly inhibited proliferation and triggered apoptosis [63].

Recently, two projects using DNA exome sequencing were performed aimed at pinpointing the responsible genes in 11q deletion for the more aggressive tumour behaviour. These groups $[64,65]$, provided similar findings to that published by Pugh et al. where it is shown that there is a low mutation rate in the genes located at $11 \mathrm{q}$ and across the genome [66]. No obvious gene with second hit mutations along with 11q deletion was identified [66]. This result is in agreement with the global view of the NB mutation profile, which exhibits surprisingly only a low number of point mutations, suggesting that tumorigenesis is more reliant on larger chromosomal rearrangements. In addition there is a lack of functional studies for many of these $11 \mathrm{q}$ genes making proper conclusions based on gene function harder.

Although 11q has been investigated with the intent on finding tumour suppressor genes, it also harbours several oncogenes that appear to play a role in the development of $\mathrm{NB}$ and could present themselves as interesting targets for therapy. Cyclin D1 (CCND1) (11q13.3) maps into the retain side of $11 \mathrm{q}$ breakpoint region. Rearrangements and copy number gains resulting in over-expression have been described in both tumours and cell lines [67, 68]. CCND1 in complex with CDK4/CDK6 regulates G1/S transition and its oncogenic role in cancer has been largely associated with the inactivation of $\mathrm{pRB}$. In NB, inhibition of CCND1 and its targets CDK4/CDK6 resulted in reduced cell proliferation, cell cycle arrest and neuronal differentiation [69]. Targeting CCND1 in NB through CDK4/CDK6 inhibition has attracted attention and is currently in preclinical studies [70, 71].

NCAM (11q23.2) is a well-known tumour marker expressed on NB whose higher expression is associated with increased metastasis at diagnosis and advanced disease [72]. Further studies in vitro and in animal models 
suggested that poly-sialinization of NCAM promotes dissemination of tumour cell lines by reducing the adhesiveness of cells [73]. Two enzymes, ST8SialII and ST8SialIV, carry out poly-sialinization of NCAM. Interestingly, expression of ST8SialIV but not ST8SialII is induced by retinoic acid and leads to increase in NCAM poly-sialinization [74]. In line with these observations, Al-Saraireh et al. reported that inhibition of ST8Siall by cytidine monophosphate decreases surface poly-sialinization and migration of cells in vitro [75] suggesting that NCAM or poly-sialinization enzymes could be alternative specific targets for NB treatment. Mouse model of $7 \mathrm{NB}$ xenografts treated with the IMGN901 showed an objective response in 3 cell lines all having high and homogenous IHC staining for NCAM (CD56) [76] providing further evidence that NCAM could be interesting target for NB treatment.

An interesting candidate investigated was CHK1 (11q24.2) for which pharmacological inhibitors exist and could present a novel avenue for treatment of NB [77]. Simultaneously inhibiting both Wee1 and Chk1 resulted in a marked effect on tumour size [78]. Further investigation of $C H K 1$ showed that its inhibition induces PP2A tumour suppressor activity resulting in de-phosphorylation of MYC and impaired cancer survival [79]. Additional studies investigating cell cycle demonstrated $\mathrm{S}$ phase arrest and progression towards apoptosis after $C H K 1$ inhibition [80]. Although CHK1 seems to play oncogenic role in NB, it also acts as a tumour suppressor as demonstrated in other cancers. CHK1 is well known to be involved in cell cycle control and chromosomal stability [81, 82]. In NB, 11q deletion could lead to haplo-insufficiency of this function proving beneficial for development of more aggressive phenotype but complete inhibition of CHK1 might prove too detrimental as it could cause mitotic catastrophe and ultimate cell death $[83,84]$.

\section{Methylation pattern of 11q}

Dedicated studies exploring methylation of 11q chromosome are sparse. The most current and probably most thorough dataset is that produced by Decock et al. [85]. Although the dataset does not specifically study samples with 11q deletion, researchers excluded NBs with MNA. In addition stage $4 \mathrm{NBs}$ were separated in two groups: stage 4S (NBs known to have good prognosis despite metastatic disease and low frequency of $11 \mathrm{q}$ deletions (4\%)) and stage 4 (high risk NBs) which would further enrich the cohort for NBs with 11q deletion. Stage 4 NBs were compared to stage $4 \mathrm{~S}$ or stage $1 / 2$ disease [85].

Only 3 different $11 \mathrm{q}$ hyper-methylation sites were found when comparing HR stage 4 to stage 1 and 2 NBs and only 2 were in the vicinity of genes. One is located within 11q23 close to miR4492 whose function is unknown. The other near USP35 (11q14) which could be another candidate gene but the significance of this finding is questionable as its location is not frequently affected by 11q deletion.

Comparing HR stage 4 to stage $4 S$ yielded 11 hypermethylated genes. Perhaps the most interesting of these targets is HepaCAM (11q24.2), a gene already known to play a tumour suppressor role in different cancers $[86,87]$ and already found hyper-methylated in these neoplasias [86]. Even though methylation identified only a few potential genes undergoing second hit, it is of particular interest that changes in methylation appears to affect 11q chromosome surprisingly little. These results are supported by the above-mentioned methylation and functional studies of particular genes [52, 88], where researchers were not able to find indices of hyper-methylation. Fisher et al. also obtained similar result where no major difference in expression of dysregulated genes between favourable or unfavourable NBs with 11q deletions was observed [22].

\section{mRNA expression profiling by DNA microarrays}

The advent of DNA microarrays brought about a new approach to finding potential candidates genes associated with 11q deletion and NB aggressiveness. However, only a few dedicated mRNA expression profiling studies on NB with 11q deletion have been performed. Early results uncovered specific expression patterns associated with 11q deletion that were different to gene expression pattern of MNA or low risk NBs [54], supporting the view that NBs with $11 \mathrm{q}$ deletion represent a separate molecular entity. Wang et al. similarly showed that NBs with $11 \mathrm{q}$ deletion have a specific mRNA expression profile, distinct from NBs with normal 11q. Different genes located in the 11q13-11qter region were proposed as candidate genes, possibly implicated in the aggressive phenotype of this subgroup of NBs, but no functional analysis was performed [23]. A more detailed analysis published by Fischer et al. showed that within NBs with 11q deletion, two distinct groups with different prognosis could be established [22]. Interestingly, while favourable tumours with and without 11q deletion showed similar mRNA profiles, major downregulation of the genes located in $11 \mathrm{q}$ was detected only in unfavourable NBs with 11q deletion. In order to identify possible differences in the size of $11 \mathrm{q}$ deletion between the 11q favourable NB and 11q unfavourable groups, CGH analysis was performed showing no major difference between both groups. Altogether, these results indicate that NB with 11q loss comprises two biological and clinical distinct subgroups, they also indicate that in the unfavourable group, 11q deletion affects the expression levels of many genes located in 11q. Unfortunately, no functional studies were performed in this study thus potentially responsible gene were not identified [22]. 


\section{miRNAs of $11 \mathrm{q}$}

Four genes, encoding for miR4301, miR-125b-1, let-7a and miR-100 are located in the 11q23.3 SRO region (Fig. 2). MiR-125b-1, let-7a and miR-100 are clustered together and the whole cluster is evolutionary conserved $[89,90]$. In addition, $m i R-100$ and $m i R-125 b-1$ show considerable sequence homology $[89,90]$. MiR-125 is known to be implicated in the differentiation of neurons [91] and astrocytes [92] as well as in the plasticity of synapses [93]. In addition, Laneve et al. showed that miR-125 is also implicated in regulating NB cell growth through repression of truncated isoform of the neurotrophin receptor tropomyosin-related kinase C [94].

The let-7 miRNA family has been shown to repress clonogenic growth of NB cell lines by targeting $M Y C N$ mRNA, suggesting that loss of chromosome 11q could increase levels of $M Y C N$ [95]. Further investigation by Molenaar et al. confirmed these results and expanded the experiments to an animal model showing that lin28B is able to repress let-7 miRNA and increase MYCN protein levels inducing the development of NB [96]. This result is in accordance with observations obtained in other cancers showing that let-7a has tumour suppressor capabilities [97-100]. Closer investigation of let-7 miRNA family on chick sympathetic ganglia confirmed lin28B and let-7a functional roles described above but in contrast lin28B did not affect let-7a expression [101]. A recent study by Powers et al. again confirmed the above described observations but they further demonstrated that MYCN gene is able to sponge the expression of let-7 family members thereby relieving selective pressure to lose let-7 miRNA through 11q and 3p chromosomal deletions, giving possible explanation of why $M Y C N$ and 11qdeletions are rarely found together [102]. Association studies found correlation between SNP rs17065417 in lin $28 B$ with susceptibility to NB and expression of let-7 $[103,104]$. Important targets include oncogene RAN and convergence of lin28B/RAN signalling on Aurora kinase A activity [104] and HACE1 [103]. In addition to $M Y C N$, let-7a also binds and modulates expression of $K-R A S$, another important oncogene frequently mutated in NBs [105]. The importance of losing let-7a as a result of $11 \mathrm{q}$ deletion may be related to the modulation of $K-R A S$ however this hypothesis remains questionable as no association of 11q deletion and expression of $K-R A S$ has been found (R2, ID: GSE3960, R2 internal identifier: ps_avgpres_xtnbmaris101_u95a).

Although there is no publication describing the role of miR-100 in NBs, its association with tumour development is well established but controversial. In breast cancer, silencing of miR-100 initiated apoptosis [106] and the same effect was also observed in gastric tumour [107]. High miR-100 expression in renal carcinoma cells was associated with poorer prognosis [108], but not in hepatocellular carcinoma where downregulation of miR-100 was associated with poorer cell differentiation and shorter recurrence-free survival, while activation of miR-100 repressed metastasis [109]. In oesophageal squamous cell carcinoma [110], colorectal cancer [111], bladder carcinoma [112] and ovarian cancer [113] miR-100 downregulation was generally found to be associated with a poorer prognosis. In addition, miR-100 was shown to downregulate $A T M$ and by this way, sensitize glioma cell lines to irradiation [114].

Other miRNAs located on 11q that have been studied in association with tumour biology include miR708 (11q14.1), miR34b (11q23.1) and miR34c (11q23.1). Similar to miR-100, evidence on miR708 is conflicting, with some studies reporting tumour suppressor properties in glioblastoma [115], renal cancer [116], ovarian cancer [117] and hepatocellular carcinoma [118] and others reporting oncogenic properties in bladder [119] and non-small cell lung cancers [120]. One of the most downregulated miRNAs in NB cell lines compared to normal adrenal glands was $\mathrm{miR} 34 \mathrm{~b} / \mathrm{c}$. Similar results were also found in a mouse NB progression model. Furthermore, treatment with $5^{\prime}$-AZA demethylation agent successfully re-established expression of miR34b/c, while miRNA mimic successfully decreased NB proliferation rate [121]. In support of these results in NB, it was shown that epigenetic inactivation in multiple myeloma and restoration of their expressions led to reduced cell proliferation and enhanced apoptosis [122]. Interestingly, both miRNAs appear to be under transcriptional control of p53 as they are upregulated when p53 is activated by Nutlin3a, inducing senescence [123]. Polymorphisms in the promoter region of $\mathrm{miR} 34 \mathrm{~b} / \mathrm{c}$ are also implicated in higher risk for development of cancer [124].

Other validated or provisonal miRNAs genes located on 11q include: miR5579, miR3166, miR1261, miR4300, miR4490, miR1304, miR1260B, miR3920, miR4693, miR4491, miR4301, miR4492, miR4493, miR3167 but their functions are unknown.

Investigations on expression of global miRNA profile in NB with 11q loss showed a similar picture with that of mRNA profile. Buckley et al. showed that NBs patients with 11q-deleted could be divided into high and low risk groups based on their expression profile of only 15 miRNAs. Interestingly, the miRNA profile of higher risk patients also correlated with more chromosomal abnormalities, but no other chromosomal abnormality was significantly associated with it [14].

\section{Haplo-insufficiency}

Due to the lack of concrete findings of the abovedescribed efforts for identifying gene(s) responsible for the increased NB aggressiveness, it was proposed that 11q deletion may be a case of haplo-insufficiency. In 
order to understand which pathways might be affected by haplo-insufficiency when $11 \mathrm{q}$ is lost, we have extracted a list of genes located on 11q14 - 11qter and a list of genes located in the SRO broad region (Fig. 2). Then using gene enrichment analysis (IPA software), we were able to identify molecular pathways most extensively affected by $11 \mathrm{q}$ deletion (Table 1 ). Certain genes identified in these pathways include: matrix metalloproteinases (known to be an important re-modellators of extracellular proteins), genes involved in bladder cancer signalling and HIF1a signalling, genes involved in immune response such as granulocyte and agranulocyte adhesion and diapedesis, leukocyte extravasation signalling and inflamasome pathway were also present. Interestingly $11 \mathrm{q}$ seems to also hold a high number of genes involved in apoptosis and cell death of kidney cell lines, lipid metabolism and uptake of potassium ions.

\section{The timing of the $11 \mathrm{q}$ and its location in the different cellular components of neuroblastic tumours}

Precise timing of $11 \mathrm{q}$ deletion is not yet fully understood. It's increasing frequency with stage, being $8 \%$ in stage 1 and 52\% in stage 4 [27] and older age of NB onset [5], could suggest a late stage event. Other hypothesis of being early stage event persisting after birth is possible as well. Interestingly, a recent research analysing of stage 4 and $4 \mathrm{~S} \mathrm{NB}$, suggests that 11q loss might appear at early stages of metastatic tumorigenesis, preceding $3 p$ loss [125]. CGH analysis of ganglioneuroblastoma (GNB) showed no $11 \mathrm{q}$ deletion, suggesting that this event might occur rarely in this less aggressive NB subgroup
[126]. Similar results were obtained by Coco et al. and Bourdeaut et al. where CGH did not show any abnormalities at chromosome 11 in ganglioneuroma (GN) and GNB intermixed, while 11q loss was detected in NB $[127,128]$.

Although neuroblastic tumours are very heterogeneous tumours composed of variable proportion of neuroblastic and Schwannian stromal cells, the common origin of both component and the neoplastic nature of Schwann cells were highly debated [127-132]. In 2008, Bourdeaut et al. were able to show by using X-linked inactivation and CGH, that neuroblastic and Schwannian stromal cells develop from the same GNB progenitor but later undergo separate development [128]. In this study, while all neuroblastic components showed chromosomal imbalance (4/6 with $11 \mathrm{q}$ loss), no alteration was observed in the Schwann cells area, pointing to the likely possibility that $11 \mathrm{q}$ is acquired at the stage where the neuroblastic component is already differentiated from Schwann cells stroma [128]. More recently, Angelini et al. reported that ganglion cells, but not Schwann cells, of nodular GNB showed similar genetic alterations detected in the neuroblastic component. In this study, 5 of 8 nodular GNB showed 11q loss in neuroblastic cells. When tested, 11q loss was also detected in the ganglioneuromatous component of the tumour, but not in Schwann cells. Altogether, the results obtained from using SNP arrays and FISH suggest that Schwann cells have a different origin and are not clonally related to the other compounds [133].

\section{Conclusions}

During the past 25 years, substantial efforts have been invested in trying to understand the molecular changes

Table 1 Comparison of differences in enrichment analysis between different 11q deletion segments

\begin{tabular}{|c|c|c|c|c|c|c|c|}
\hline \multicolumn{2}{|c|}{ Diseases and Biological pathways } & \multicolumn{2}{|l|}{ Toxicological functions } & \multicolumn{2}{|c|}{ Upstream regulators } & \multicolumn{2}{|l|}{ Canonical pathways } \\
\hline 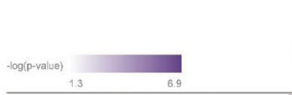 & 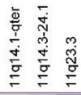 & ${ }^{-\log (\beta-v a l u e)}{ }_{1.3}$ & 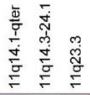 & $\begin{array}{ll}-0.1 \\
\end{array}$ & 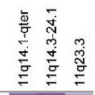 & ${ }^{-\log (\text { pralue) }}{ }_{1.3}$ & 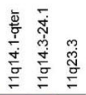 \\
\hline refractory adult Philadelphia chromosome ne... & & familial atrial fibrilation & & THRB & & Inhibition of Matrix Metalloproteases & \\
\hline relapsed adult Philadelphia chromosome neg... & & long-QT syndrome 10 & & APOC3 & & Granulocyte Achesion and Diapedesis & \\
\hline secretion of triacylglycerol & & nephronophthisis 15 & & IL1 & & Atherosclerosis Signaling & \\
\hline quantity of vitamin A & & familial atrial fibrillation type 14 & & PPARA & & Bladder Cancer Signaling & \\
\hline osteoarthritis & & apoptosis of kidney cell lines & & ETV & & HIF1a Signaling & \\
\hline Hypertriglyceridemia & & increased uptake of $\mathrm{K}_{+}$ & & OCLN & & Leukocyte Extravasation Signaling & \\
\hline homeostasis of triacylglycerol & & hydronephrosis & & $\mathrm{NRTH4}$ & & Agranulocyte Adhesion and Diapedesis & \\
\hline homeostasis of cholesterol & & cell death of kidney cell lines & & NR1H3 & & LXR/RXR Activation & \\
\hline transport of molecule & & non-rheumatic aortic stenosis & & RAF1 & & Cytotoxic T Lymphocyte-mediated Apoptosis.. & \\
\hline catabolism of protein & & early-onset premature coronary artery disease & & PRSS2 & & Inflammasome pathway & \\
\hline concentration of triacylglycerol & & obstructive jaundice & & UBA1 & & Amyotrophic Lateral Sclerosis Signaling & \\
\hline efflux of phospholipid & & atrial fibrillation & & $\mathrm{lkb}$ & & T Cell Receptor Signaling & \\
\hline myoclonic dystonia & & familial arrhythmia & & RORA & & Hematopoiesis from Pluripotent Stem Cells & \\
\hline $\begin{array}{l}\text { early-onset breast cancer } \\
\text { import of cholesterol }\end{array}$ & & long QT syndrome type 13 & & SMARCA4 & & $\begin{array}{l}\text { Colorectal Cancer Metastasis Signaling } \\
\text { CTLA4 Signaling in Cytotoxic T Lymphocytes }\end{array}$ & \\
\hline $\begin{array}{l}\text { import of cholesterol } \\
\text { familial amyloidosis }\end{array}$ & & brugada syndrome type 7 & & $\begin{array}{l}\text { FOS } \\
\text { APOAI }\end{array}$ & & $\begin{array}{l}\text { Nur77 Signaling in T Lymphocytes } \\
\text { Sucytes }\end{array}$ & \\
\hline tauopathy & & Romano-Ward syndrome & & USP19 & & OX40 Signaling Pathway & \\
\hline proteolysis & & Andersen's syndrome & & ABL2 & & Role of Osteoblasts, Osteoclasts and Chondro. & \\
\hline efflux of cholesterol & & & & HTRAI & & Clathrin-mediated Endocytosis Signaling & \\
\hline & & & & PRKGI & & Calcium-induced T Lymphocyte Apoptosis & \\
\hline & & & & & & CCR5 Signaling in Macrophages & \\
\hline
\end{tabular}

For the bioinformatics analysis IPA software was used. Annotated genes located on the most frequent 11q deleted region (11q14.1-qter from PAK to SNX), broad SRO (11q14.3-24.1 from miR-4490 to miR-100) and narrow SRO region (11q23.3 from CADM1 to TRIM29) was used. All three gene sets were ranked for Disease and Biological pathways, Toxicological Functions, Upstream regulators and Canonical pathways (in table only significant are shown). Fisher exact test was used for determination of enrichment and $p$-value less than 0.05 was used as significant. The rank score represents the ratio of $11 q$ deleted genes contained in a specific network in comparison to the whole list of genes involved in the same specific network 
that lead to more aggressive NB tumours. As very few mutations have been detected despite large international efforts, recurrent patterns of NCA or SCA suggest that $\mathrm{NB}$ is most probably a cancer driven by copy number rather than by specific mutations. Using classical cytological methods, 11q deletion was identified as one of the main events associated with poorer prognosis. Further molecular characterization using $\mathrm{LOH}$ and microarrays CGH or SNPs, pinpointed a possible SRO within 11q. The observation that $11 \mathrm{q}$ is never lost on both chromosomes lead to the suggestions that vitally important genes must be present on the remaining $11 \mathrm{q}$, but that the second hit needed would logically be caused by a smaller localized mutation or methylation event. However, research aimed at pinpointing the culprit gene through sequencing and methylation has yielded unsubstantial results.

Due to the unsuccessful efforts despite using the latest sequencing technologies, it seems unlikely that classic single unifying tumour suppressor gene explanation exists for 11q deletion. Because of that, it has been proposed that $11 \mathrm{q}$ deletion might be a case of haplo-insufficiency. An alternative approach for identifying the 11q locus(i) responsible for the 11q loss phenotype might be possible with CRISPR/Cas9 genomic editing. Although only a few publications exist for this application, it has demonstrated that creating gross deletions using a two guided RNA system is possible. A deletion of up to $1 \mathrm{Mbp}$ has an efficiency of around 1 to $2 \%$, sufficient for the generation of such clones with proper automatization equipment. It was demonstrated that deletions of up to $60 \mathrm{Mbp}$ are possible. Such technology could prove a powerful tool for studying haplo-insufficiency by deleting progressively narrower regions and determining their contribution to tumorigenesis or aggressiveness at every stage by standard cytological methods. Developing such models of $11 \mathrm{q}$ deletions would be an essential first step to defining therapeutic vulnerabilities for this group of patients.

\section{Abbreviations \\ CGH: Comparative genomics hybridization; CIN: Chromosomal instability; DNA: Des oxyribonucleic acid; ECARUCA: European Cytogeneticist Association Register of Unbalanced Chromosome Aberrations; EFS: Event free survival; FISH: Fluorescence in situ hybridization; GN: Ganglioneuroma; GNB: Ganglioneuroblastoma; HR: High risk; IPA: Ingenuity Pathway Analysis; LOH: Loss of heterozygosity; MNA: MYCN amplification; NB: Neuroblastoma; NCA: Numerical chromosome aberrations; OS: Overall survival; SCA: Segmental chromosomal aberrations; SNP: Single nucleotide polymorphism; SRO: Smallest region of overlap}

\section{Acknowledgements}

We would like to thank Anna-Rita Farina for her generous help and access to IPA and Patricia Huezo-Diaz Curtis for English editing.

\section{Funding}

This work was supported by: the CANSEARCH Foundation, the Le Printemps des Enfants, the Fondation pour la lutte contre le cancer et pour des recherches médico-biologiques, the Fondation Gustave et Simone Prévot, the Association Hubert Gouin - Enfance \& Cancer, the Ligue Genevoise contre le Cancer and the Giulio D'Angio Endowed Chair.

\section{Availability of data and materials}

The datasets analysed during the current study are available in the following repositories:

ECARUCA: http://umcecaruca01.extern.umcn.nl:8080/ecaruca/ecaruca.jsp

ENSEMBL: http://www.ensembl.org/index.html

TARGET data matrix: https://target-data.nci.nih.gov/Public/NBL/copy_number_ array/L3/

\section{Authors' contributions}

VM, FGP conceived this work. VM, SJM, GL, JMM, MA, FGP: preparation of manuscript. SJM, GL: preparation of Fig. 1. SJM: preparation of Table 1, Fig. 2 and analysis with IPA. VM, SJM, GL, JMM, MA, FGP: critical discussion. All authors read and approved the final manuscript.

Ethics approval and consent to participate

Not applicable.

\section{Consent for publication}

Not applicable.

\section{Competing interests}

All authors declare that they have no competing interests.

\section{Publisher's Note}

Springer Nature remains neutral with regard to jurisdictional claims in published maps and institutional affiliations.

\section{Author details}

${ }^{1}$ CANSEARCH Research Laboratory, Geneva University Medical School, Avenue de la Roseraie 64, 1205 Geneva, Switzerland. ${ }^{2}$ Department of Pediatrics, Onco-Hematology Unit, Geneva University Hospitals, Rue Willy-Donzé 6, 1205 Geneva, Switzerland. ${ }^{3}$ Division of Oncology and Center for Childhood Cancer Research, Children's Hospital of Philadelphia, Philadelphia, PA, USA. ${ }^{4}$ Department of Pediatrics, Perelman School of Medicine at the University of Pennsylvania, Philadelphia, PA, USA.

Received: 15 May 2017 Accepted: 25 June 2017

Published online: 29 June 2017

\section{References}

1. Maris JM, Hogarty MD, Bagatell R, Cohn SL. Neuroblastoma. Lancet. 2007:369:2106-20

2. Pizzo PA, Poplack DG. Principles and Practice of Pediatric Oncology. Philadelphia: Sixth ed: Wolters Kluwer Health / Lippincott Williams and Wilkins; 2010.

3. Encinas M, Iglesias M, Liu Y, Wang H, Muhaisen A, Cena V, et al. Sequential treatment of SH-SY5Y cells with retinoic acid and brain-derived neurotrophic factor gives rise to fully differentiated, neurotrophic factor-dependent, human neuron-like cells. J Neurochem. 2000;75:991-1003.

4. Fernandes ND, Sun Y, Price BD. Activation of the kinase activity of ATM by retinoic acid is required for $C R E B$-dependent differentiation of neuroblastoma cells. J Biol Chem. 2007;282:16577-84.

5. Caren H, Kryh H, Nethander M, Sjoberg RM, Trager C, Nilsson S, et al. High-risk neuroblastoma tumors with 11q-deletion display a poor prognostic chromosome instability phenotype with later onset. Proc Natl Acad Sci U S A. 2010:107:4323-8.

6. Schleiermacher $G$, Janoueix-Lerosey I, Delattre O. Recent insights into the biology of neuroblastoma. Int J Cancer. 2014;135:2249-61.

7. Janoueix-Lerosey I, Schleiermacher G, Michels E, Mosseri V, Ribeiro A, Lequin D, et al. Overall genomic pattern is a predictor of outcome in neuroblastoma. J Clin Oncol. 2009;27:1026-33.

8. Schleiermacher G, Michon J, Huon I, d'Enghien CD, Klijanienko J, Brisse H, et al. Chromosomal CGH identifies patients with a higher risk of relapse in neuroblastoma without MYCN amplification. Br J Cancer. 2007;97:238-46.

9. Cohn SL, Pearson AD, London WB, Monclair T, Ambros PF, Brodeur GM, et al. The international Neuroblastoma risk group (INRG) classification system: an INRG task force report. J Clin Oncol. 2009:27:289-97.

10. Matthay KK, Maris JM, Schleiermacher G, Nakagawara A, Mackall CL, Diller L, et al. Neuroblastoma. Nat Rev Dis Primers. 2016;2:16078.

11. Maris JM, Guo C, White PS, Hogarty MD, Thompson PM, Stram DO, et al. Allelic deletion at chromosome bands 11q14-23 is common in neuroblastoma. Med Pediatr Oncol. 2001;36:24-7. 
12. Mertens F, Johansson B, Hoglund M, Mitelman F. Chromosomal imbalance maps of malignant solid tumors: a cytogenetic survey of 3185 neoplasms. Cancer Res. 1997;57:2765-80.

13. Srivatsan ES, Ying KL, Seeger RC. Deletion of chromosome 11 and of $14 \mathrm{q}$ sequences in neuroblastoma. Genes Chromosomes Cancer. 1993;7:32-7.

14. Buckley PG, Alcock L, Bryan K, Bray I, Schulte JH, Schramm A, et al. Chromosomal and microRNA expression patterns reveal biologically distinct subgroups of 11q- neuroblastoma. Clin Cancer Res. 2010;16:2971-8.

15. Guo C, White PS, Weiss MJ, Hogarty MD, Thompson PM, Stram DO, et al. Allelic deletion at 11q23 is common in MYCN single copy neuroblastomas. Oncogene. 1999;18:4948-57.

16. Plantaz D, Vandesompele J, Van Roy N, Lastowska M, Bown N, Combaret V, et al. Comparative genomic hybridization $(\mathrm{CGH})$ analysis of stage 4 neuroblastoma reveals high frequency of 11 q deletion in tumors lacking MYCN amplification. Int J Cancer. 2001;91:680-6.

17. Spitz R, Hero B, Ernestus K, Berthold F. Deletions in chromosome arms $3 p$ and $11 \mathrm{q}$ are new prognostic markers in localized and 4 s neuroblastoma. Clin Cancer Res. 2003;9:52-8.

18. Michels E, Vandesompele J, De Preter K, Hoebeeck J, Vermeulen J, Schramm A et al. ArrayCGH-based classification of neuroblastoma into genomic subgroups. Genes Chromosomes Cancer. 2007:46:1098-108.

19. Mosse YP, Diskin SJ, Wasserman N, Rinaldi K, Attiyeh EF, Cole K, et al. Neuroblastomas have distinct genomic DNA profiles that predict clinical phenotype and regional gene expression. Genes Chromosomes Cancer. 2007:46:936-49.

20. Vandesompele J, Baudis M, De Preter K, Van Roy N, Ambros P, Bown N, et al. Unequivocal delineation of clinicogenetic subgroups and development of a new model for improved outcome prediction in neuroblastoma. J Clin Oncol. 2005:23:2280-99.

21. Attiyeh EF, London WB, Mosse YP, Wang Q, Winter C, Khazi D, et al. Chromosome $1 p$ and $11 q$ deletions and outcome in neuroblastoma. $\mathrm{N}$ Engl J Med. 2005:353:2243-53.

22. Fischer M, Bauer T, Oberthur A, Hero B, Theissen J, Ehrich M, et al. Integrated genomic profiling identifies two distinct molecular subtypes with divergent outcome in neuroblastoma with loss of chromosome 11q. Oncogene. 2010;29:865-75

23. Wang Q, Diskin S, Rappaport E, Attiyeh E, Mosse Y, Shue D, et al. Integrative genomics identifies distinct molecular classes of neuroblastoma and shows that multiple genes are targeted by regional alterations in DNA copy number. Cancer Res. 2006;66:6050-62.

24. Caron H, van Sluis P, de Kraker J, Bokkerink J, Egeler M, Laureys G, et al. Allelic loss of chromosome $1 p$ as a predictor of unfavorable outcome in patients with neuroblastoma. N Engl J Med. 1996;334:225-30.

25. Luttikhuis ME, Powell JE, Rees SA, Genus T, Chughtai S, Ramani P, et al. Neuroblastomas with chromosome 11q loss and single copy MYCN comprise a biologically distinct group of tumours with adverse prognosis. Br J Cancer. 2001;85:531-7.

26. Maris JM, Weiss MJ, Guo C, Gerbing RB, Stram DO, White PS, et al. Loss of heterozygosity at 1 p36 independently predicts for disease progression but not decreased overall survival probability in neuroblastoma patients: a Children's cancer group study. J Clin Oncol. 2000;18:1888-99.

27. Spitz R, Hero B, Simon T, Berthold F. Loss in chromosome 11q identifies tumors with increased risk for metastatic relapses in localized and 45 neuroblastoma. Clin Cancer Res. 2006;12:3368-73.

28. Coco S, Theissen J, Scaruffi P, Stigliani S, Moretti S, Oberthuer A, et al. Agedependent accumulation of genomic aberrations and deregulation of cell cycle and telomerase genes in metastatic neuroblastoma. Int J Cancer. 2012;131:1591-600.

29. Defferrari R, Mazzocco K, Ambros IM, Ambros PF, Bedwell C, Beiske K, et al. Influence of segmental chromosome abnormalities on survival in children over the age of 12 months with unresectable localised peripheral neuroblastic tumours without MYCN amplification. Br J Cancer. 2015;112:290-5.

30. Cetinkaya C, Martinsson T, Sandgren J, Trager C, Kogner P, Dumanski J, et al. Age dependence of tumor genetics in unfavorable neuroblastoma: arrayCGH profiles of 34 consecutive cases, using a Swedish 25-year neuroblastoma cohort for validation. BMC Cancer. 2013;13:231.

31. George RE, Attiyeh EF, Li S, Moreau LA, Neuberg D, Li C, et al. Genome-wide analysis of neuroblastomas using high-density single nucleotide polymorphism arrays. PLoS One. 2007;2:e255.

32. Meany HJ, London WB, Ambros PF, Matthay KK, Monclair T, Simon T, et al. Significance of clinical and biologic features in stage 3 neuroblastoma: a report from the international Neuroblastoma risk group project. Pediatr Blood Cancer. 2014:61:1932-9.

33. Vandesompele J, Van Roy N, Van Gele M, Laureys G, Ambros P, Heimann P, et al. Genetic heterogeneity of neuroblastoma studied by comparative genomic hybridization. Genes Chromosomes Cancer. 1998;23:141-52.

34. Bogen D, Brunner C, Walder D, Ziegler A, Abbasi R, Ladenstein RL, et al. The genetic tumor background is an important determinant for heterogeneous MYCN-amplified neuroblastoma. Int J Cancer. 2016;139:153-63.

35. Tomioka N, Oba S, Ohira M, Misra A, Fridlyand J, Ishii S, et al. Novel risk stratification of patients with neuroblastoma by genomic signature, which is independent of molecular signature. Oncogene. 2008;27:441-9.

36. Villamon E, Berbegall AP, Piqueras M, Tadeo I, Castel V, Djos A, et al. Genetic instability and intratumoral heterogeneity in neuroblastoma with MYCN amplification plus 11q deletion. PLoS One. 2013;8:e53740.

37. Berbegall AP, Villamon E, Piqueras M, Tadeo I, Djos A, Ambros PF, et al. Comparative genetic study of intratumoral heterogenous MYCN amplified neuroblastoma versus aggressive genetic profile neuroblastic tumors. Oncogene. 2016;35:1423-32

38. Castel V, Villamon E, Canete A, Navarro S, Ruiz A, Melero C, et al. Neuroblastoma in adolescents: genetic and clinical characterisation. Clin Transl Oncol. 2010:12:49-54.

39. Mazzocco K, Defferrari R, Sementa AR, Garaventa A, Longo L, De Mariano M, et al. Genetic abnormalities in adolescents and young adults with neuroblastoma: a report from the Italian Neuroblastoma group. Pediatr Blood Cancer. 2015;62:1725-32.

40. Cheung NK, Zhang J, Lu C, Parker M, Bahrami A, Tickoo SK, et al. Association of age at diagnosis and genetic mutations in patients with neuroblastoma. JAMA. 2012;307:1062-71.

41. Schleiermacher G, Janoueix-Lerosey I, Ribeiro A, Klijanienko J, Couturier J, Pierron $\mathrm{G}$, et al. Accumulation of segmental alterations determines progression in neuroblastoma. J Clin Oncol. 2010;28:3122-30.

42. Eleveld TF, Oldridge DA, Bernard V, Koster J, Daage LC, Diskin SJ, et al. Relapsed neuroblastomas show frequent RAS-MAPK pathway mutations. Nat Genet. 2015:47:864-71.

43. Schramm A, Koster J, Assenov Y, Althoff K, Peifer M, Mahlow E, et al. Mutational dynamics between primary and relapse neuroblastomas. Nat Genet. 2015;47:872-7.

44. Koiffmann CP, Gonzalez CH, Vianna-Morgante AM, Kim CA, Odone-Filho V Wajntal A. Neuroblastoma in a boy with MCA/MR syndrome, deletion 11q, and duplication 12q. Am J Med Genet. 1995;58:46-9.

45. Passariello A, De Brasi D, Defferrari R, Genesio R, Tufano M, Mazzocco K, et al. Constitutional 11q14-q22 chromosome deletion syndrome in a child with neuroblastoma MYCN single copy. Eur J Med Genet. 2013;56:626-34.

46. Mosse Y, Greshock J, King A, Khazi D, Weber BL, Maris JM. Identification and high-resolution mapping of a constitutional 11q deletion in an infant with multifocal neuroblastoma. Lancet Oncol. 2003;4:769-71.

47. Satge D, Moore SW, Stiller CA, Niggli FK, Pritchard-Jones K, Bown N, et al. Abnormal constitutional karyotypes in patients with neuroblastoma: a report of four new cases and review of 47 others in the literature. Cancer Genet Cytogenet. 2003;147:89-98.

48. Shiohama T, Fujii K, Hino M, Shimizu K, Ohashi H, Kambe M, et al. Coexistence of neuroblastoma and ganglioneuroma in a girl with a hemizygous deletion of chromosome 11q14.1-23.3. Am J Med Genet A. 2016;170A:492-7.

49. Bader SA, Fasching C, Brodeur GM, Stanbridge EJ. Dissociation of suppression of tumorigenicity and differentiation in vitro effected by transfer of single human chromosomes into human neuroblastoma cells. Cell Growth Differ. 1991;2:245-55

50. Michels E, Hoebeeck J, De Preter K, Schramm A, Brichard B, De Paepe A, et al. CADM1 is a strong neuroblastoma candidate gene that maps within a 3.72 Mb critical region of loss on 11q23. BMC Cancer. 2008;8:173.

51. Nowacki S, Skowron M, Oberthuer A, Fagin A, Voth H, Brors B, et al. Expression of the tumour suppressor gene CADM1 is associated with favourable outcome and inhibits cell survival in neuroblastoma. Oncogene. 2008;27:3329-38.

52. Ando K, Ohira M, Ozaki T, Nakagawa A, Akazawa K, Suenaga Y, et al. Expression of TSLC1, a candidate tumor suppressor gene mapped to chromosome 11q23, is downregulated in unfavorable neuroblastoma without promoter hypermethylation. Int J Cancer. 2008;123:2087-94.

53. Mandriota SJ, Valentijn $\sqcup$, Lesne L, Betts DR, Marino D, Boudal-Khoshbeen M, et al. Ataxia-telangiectasia mutated (ATM) silencing promotes neuroblastoma progression through a MYCN independent mechanism. Oncotarget. 2015;6:18558-76. 
54. McArdle L, McDermott M, Purcell R, Grehan D, O'Meara A, Breatnach F, et al. Oligonucleotide microarray analysis of gene expression in neuroblastoma displaying loss of chromosome 11q. Carcinogenesis. 2004;25:1599-609.

55. Wilzen A, Nilsson S, Sjoberg RM, Kogner P, Martinsson T, Abel F. The Phox2 pathway is differentially expressed in neuroblastoma tumors, but no mutations were found in the candidate tumor suppressor gene PHOX2A. Int J Oncol. 2009;34:697-705.

56. Coppola E, d'Autreaux F, Rijli FM, Brunet JF. Ongoing roles of Phox2 homeodomain transcription factors during neuronal differentiation. Development. 2010;137:4211-20.

57. Flora A, Lucchetti H, Benfante R, Goridis C, Clementi F, Fornasari D. Sp proteins and Phox $2 \mathrm{~b}$ regulate the expression of the human Phox2a gene. J Neurosci. 2001;21:7037-45.

58. Longo L, Borghini S, Schena F, Parodi S, Albino D, Bachetti T, et al. PHOX2A and $\mathrm{PHOX} 2 \mathrm{~B}$ genes are highly co-expressed in human neuroblastoma. Int J Oncol. 2008;33:985-91.

59. Mosse YP, Laudenslager M, Khazi D, Carlisle AJ, Winter CL, Rappaport E, et al. Germline PHOX2B mutation in hereditary neuroblastoma. Am J Hum Genet. 2004;75:727-30.

60. Bourdeaut F, Trochet D, Janoueix-Lerosey I, Ribeiro A, Deville A, Coz C, et al. Germline mutations of the paired-like homeobox 2B (PHOX2B) gene in neuroblastoma. Cancer Lett. 2005;228:51-8.

61. Trochet D, Bourdeaut F, Janoueix-Lerosey I, Deville A, de Pontual L, Schleiermacher $G$, et al. Germline mutations of the paired-like homeobox 2B (PHOX2B) gene in neuroblastoma. Am J Hum Genet. 2004;74:761-4.

62. De Preter K, Vandesompele J, Hoebeeck J, Vandenbroecke C, Smet J, Nuyts A et al. No evidence for involvement of SDHD in neuroblastoma pathogenesis. BMC Cancer. 2004;4:55.

63. Santo EE, Ebus ME, Koster J, Schulte JH, Lakeman A, van Sluis P, et al. Oncogenic activation of FOXR1 by 11q23 intrachromosomal deletionfusions in neuroblastoma. Oncogene. 2012;31:1571-81.

64. Molenaar JJ, Koster J, Zwijnenburg DA, van Sluis $P$, Valentijn $L$, van der Ploeg I, et al. Sequencing of neuroblastoma identifies chromothripsis and defects in neuritogenesis genes. Nature. 2012;483:589-93.

65. Lasorsa VA, Formicola D, Pignataro P, Cimmino F, Calabrese FM, Mora J, et al. Exome and deep sequencing of clinically aggressive neuroblastoma reveal somatic mutations that affect key pathways involved in cancer progression. Oncotarget. 2016;7:21840-52

66. Pugh TJ, Morozova O, Attiyeh EF, Asgharzadeh S, Wei JS, Auclair D, et al. The genetic landscape of high-risk neuroblastoma. Nat Genet. 2013:45:279-84.

67. Molenaar JJ, van Sluis P, Boon K, Versteeg R, Caron HN. Rearrangements and increased expression of cyclin D1 (CCND1) in neuroblastoma. Genes Chromosomes Cancer. 2003:36:242-9.

68. Molenaar JJ, Koster J, Ebus ME, van Sluis P, Westerhout EM, de Preter K, et al. Copy number defects of G1-cell cycle genes in neuroblastoma are frequent and correlate with high expression of E2F target genes and a poor prognosis. Genes Chromosomes Cancer. 2012;51:10-9.

69. Molenaar JJ, Ebus ME, Koster J, van Sluis P, van Noesel CJ, Versteeg R, et al. Cyclin D1 and CDK4 activity contribute to the undifferentiated phenotype in neuroblastoma. Cancer Res. 2008;68:2599-609.

70. Wood AC, Krytska K, Ryles HT, Infarinato NR, Sano R, Hansel TD, Hart LS, King FJ, Smith TR, Ainscow E, Grandinetti KB, Tuntland T, Kim S, Caponigro G, He YQ, Krupa S, Li N, Harris UL, Mossé YP. Dual ALK and CDK4/6 Inhibition Demonstrates Synergy against Neuroblastoma. Clin Cancer Res. 2017;23(11):2856-68.

71. Hart LS, Rader J, Raman P, Batra V, Russell MR, Tsang M, et al. Preclinical therapeutic synergy of MEK1/2 and CDK4/6 inhibition in Neuroblastoma. Clin Cancer Res. 2017;23:1785-96.

72. Korja M, Jokilammi A, Salmi T, Kalimo H, Pelliniemi T, Isola J, et al. Absence of polysialylated NCAM is an unfavorable prognostic phenotype for advanced stage neuroblastoma. BMC Cancer. 2009;9:57.

73. Valentiner $U$, Muhlenhoff M, Lehmann U, Hildebrandt H, Schumacher U. Expression of the neural cell adhesion molecule and polysialic acid in human neuroblastoma cell lines. Int J Oncol. 2011;39:417-24.

74. Seidenfaden R, Hildebrandt $H$. Retinoic acid-induced changes in polysialyltransferase mRNA expression and NCAM polysialylation in human neuroblastoma cells. J Neurobiol. 2001;46:11-28.

75. Al-Saraireh YM, Sutherland M, Springett BR, Freiberger F, Ribeiro Morais G, Loadman PM, et al. Pharmacological inhibition of polysialyltransferase ST8Siall modulates tumour cell migration. PLoS One. 2013;8:e73366.

76. Wood AC, Maris JM, Gorlick R, Kolb EA, Keir ST, Reynolds CP, et al. Initial testing (stage 1) of the antibody-maytansinoid conjugate, IMGN901
(Lorvotuzumab mertansine), by the pediatric preclinical testing program. Pediatr Blood Cancer. 2013;60:1860-7.

77. Walton Ml, Eve PD, Hayes A, Valenti MR, De Haven Brandon AK, Box G, et al. CCT244747 is a novel potent and selective CHK1 inhibitor with oral efficacy alone and in combination with genotoxic anticancer drugs. Clin Cancer Res. 2012:18:5650-61.

78. Russell MR, Levin K, Rader J, Belcastro L, Li Y, Martinez D, et al. Combination therapy targeting the Chk1 and Wee1 kinases shows therapeutic efficacy in neuroblastoma. Cancer Res. 2013;73:776-84.

79. Khanna A, Kauko O, Bockelman C, Laine A, Schreck I, Partanen Jl, et al. Chk1 targeting reactivates PP2A tumor suppressor activity in cancer cells. Cancer Res. 2013;73:6757-69.

80. Cole KA, Huggins J, Laquaglia M, Hulderman CE, Russell MR, Bosse K, et al. RNAi screen of the protein kinome identifies checkpoint kinase 1 (CHK1) as a therapeutic target in neuroblastoma. Proc Natl Acad Sci U S A. 2011;108:3336-41.

81. Nghiem P, Park PK, Kim Y, Vaziri C, Schreiber SL. ATR inhibition selectively sensitizes G1 checkpoint-deficient cells to lethal premature chromatin condensation. Proc Natl Acad Sci U S A. 2001;98:9092-7.

82. Niida H, Tsuge S, Katsuno Y, Konishi A, Takeda N, Nakanishi M. Depletion of Chk1 leads to premature activation of Cdc2-cyclin B and mitotic catastrophe. J Biol Chem. 2005;280:39246-52.

83. Zuazua-Villar P, Rodriguez R, Gagou ME, Eyers PA, Meuth M. DNA replication stress in CHK1-depleted tumour cells triggers premature (S-phase) mitosis through inappropriate activation of aurora kinase B. Cell Death Dis. 2014:5:e1253.

84. Carrassa L, Damia G. Unleashing Chk1 in cancer therapy. Cell Cycle. 2011;10:2121-8.

85. Decock A, Ongenaert M, De Wilde B, Brichard B, Noguera R, Speleman F, Vandesompele J. Stage 4S neuroblastoma tumors show a characteristic DNA methylation portrait. Epigenetics. 2016;11:761-71.

86. Moh MC, Zhang T, Lee LH, Shen S. Expression of hepaCAM is downregulated in cancers and induces senescence-like growth arrest via a p53/p21-dependent pathway in human breast cancer cells. Carcinogenesis. 2008;29:2298-305.

87. Zhang QL, Luo CL, Wu XH, Wang CY, Xu X, Zhang YY, et al. HepaCAM induces $\mathrm{G} 1$ phase arrest and promotes c-Myc degradation in human renal cell carcinoma. J Cell Biochem. 2011;112:2910-9.

88. Gumy-Pause F, Pardo B, Khoshbeen-Boudal M, Ansari M, Gayet-Ageron A, Sappino AP, et al. GSTP1 hypermethylation is associated with reduced protein expression, aggressive disease and prognosis in neuroblastoma. Genes Chromosomes Cancer. 2012;51:174-85.

89. Grimson A, Srivastava M, Fahey B, Woodcroft BJ, Chiang HR, King N, et al. Early origins and evolution of microRNAs and Piwi-interacting RNAs in animals. Nature. 2008;455:1193-7.

90. Sokol NS. Small temporal RNAs in animal development. Curr Opin Genet Dev. 2012:22:368-73.

91. Le MT, Xie H, Zhou B, Chia PH, Rizk P, Um M, et al. MicroRNA-125b promotes neuronal differentiation in human cells by repressing multiple targets. Mol Cell Biol. 2009:29:5290-305.

92. Shenoy A, Danial M, Blelloch $\mathrm{RH}$. Let-7 and miR-125 cooperate to prime progenitors for astrogliogenesis. EMBO J. 2015:34:1180-94.

93. Akerblom M, Petri R, Sachdeva R, Klussendorf T, Mattsson B, Gentner B, et al. microRNA-125 distinguishes developmentally generated and adult-born olfactory bulb interneurons. Development. 2014;141:1580-8.

94. Laneve P, Di Marcotullio L, Gioia U, Fiori ME, Ferretti E, Gulino A, et al. The interplay between microRNAs and the neurotrophin receptor tropomyosinrelated kinase $C$ controls proliferation of human neuroblastoma cells. Proc Natl Acad Sci U S A. 2007;104:7957-62.

95. Buechner J, Tomte E, Haug BH, Henriksen JR, Lokke C, Flaegstad T, et al. Tumour-suppressor microRNAs let-7 and mir-101 target the proto-oncogene MYCN and inhibit cell proliferation in MYCN-amplified neuroblastoma. Br J Cancer. 2011;105:296-303.

96. Molenaar JJ, Domingo-Fernandez R, Ebus ME, Lindner S, Koster J, Drabek K, et al. LIN28B induces neuroblastoma and enhances MYCN levels via let-7 suppression. Nat Genet. 2012;44:1199-206.

97. Helland A, Anglesio MS, George J, Cowin PA, Johnstone CN, House CM, et al. Deregulation of MYCN, LIN28B and LET7 in a molecular subtype of aggressive high-grade serous ovarian cancers. PLoS One. 2011;6:e18064.

98. King CE, Cuatrecasas M, Castells A, Sepulveda AR, Lee JS, Rustgi AK. LIN28B promotes colon cancer progression and metastasis. Cancer Res. 2011;71:4260-8.

99. Xia Y, Zhu Y, Zhou X, Chen Y. Low expression of let-7 predicts poor prognosis in patients with multiple cancers: a meta-analysis. Tumour Biol. 2014;35:5143-8 
100. Murray MJ, Saini HK, Siegler CA, Hanning JE, Barker EM, van Dongen S, et al. LIN28 expression in malignant germ cell tumors downregulates let-7 and increases oncogene levels. Cancer Res. 2013;73:4872-84.

101. Hennchen M, Stubbusch J, Abarchan-El Makhfi I, Kramer M, Deller T, Pierre-Eugene C, et al. Lin28B and let-7 in the control of sympathetic Neurogenesis and Neuroblastoma development. J Neurosci. 2015;35:16531-44.

102. Powers JT, Tsanov KM, Pearson DS, Roels F, Spina CS, Ebright R, et al. Multiple mechanisms disrupt the let-7 microRNA family in neuroblastoma. Nature. 2016;535:246-51.

103. Diskin SJ, Capasso M, Schnepp RW, Cole KA, Attiyeh EF, Hou C, et al. Common variation at $6 \mathrm{q} 16$ within HACE1 and LIN28B influences susceptibility to neuroblastoma. Nat Genet. 2012;44:1126-30.

104. Schnepp RW, Khurana P, Attiyeh EF, Raman P, Chodosh SE, Oldridge DA, et al. A LIN28B-RAN-AURKA signaling network promotes Neuroblastoma tumorigenesis. Cancer Cell. 2015;28:599-609.

105. Langevin SM, Christensen BC. Let-7 microRNA-binding-site polymorphism in the $3^{\prime}$ UTR of KRAS and colorectal cancer outcome: a systematic review and meta-analysis. Cancer Med. 2014;3:1385-95.

106. Gong $Y, H e T$, Yang L, Yang G, Chen Y, Zhang X. The role of miR-100 in regulating apoptosis of breast cancer cells. Sci Rep. 2015;5:11650.

107. Yang G, Gong Y, Wang Q, Wang Y, Zhang X. The role of miR-100-mediated notch pathway in apoptosis of gastric tumor cells. Cell Signal. 2015;27:1087-101.

108. Wang G, Chen L, Meng J, Chen M, Zhuang L, Zhang L. Overexpression of microRNA-100 predicts an unfavorable prognosis in renal cell carcinoma. Int Urol Nephrol. 2013;45:373-9.

109. Zhou HC, Fang JH, Luo X, Zhang L, Yang J, Zhang C, et al. Downregulation of microRNA-100 enhances the ICMT-Rac1 signaling and promotes metastasis of hepatocellular carcinoma cells. Oncotarget. 2014;5:12177-88.

110. Zhou S, Yang B, Zhao Y, Xu S, Zhang H, Li Z. Prognostic value of microRNA100 in esophageal squamous cell carcinoma. J Surg Res. 2014;192:515-20.

111. Chen P, Xi Q, Wang Q, Wei P. Downregulation of microRNA-100 correlates with tumor progression and poor prognosis in colorectal cancer. Med Oncol. 2014;31:235

112. Wang S, Xue S, Dai Y, Yang J, Chen Z, Fang $X$, et al. Reduced expression of microRNA-100 confers unfavorable prognosis in patients with bladder cancer. Diagn Pathol. 2012;7:159.

113. Peng DX, Luo M, Qiu LW, He YL, Wang XF. Prognostic implications of microRNA-100 and its functional roles in human epithelial ovarian cancer. Oncol Rep. 2012;27:1238-44.

114. Ng WL, Yan D, Zhang $X$, Mo YY, Wang Y. Over-expression of miR-100 is responsible for the low-expression of ATM in the human glioma cell line: M059J. DNA Repair (Amst). 2010;9:1170-5.

115. Guo P, Lan J, Ge J, Nie Q, Mao Q, Qiu Y. miR-708 acts as a tumor suppressor in human glioblastoma cells. Oncol Rep. 2013;30:870-6.

116. Saini S, Yamamura S, Majid S, Shahryari V, Hirata H, Tanaka Y, et al. MicroRNA-708 induces apoptosis and suppresses tumorigenicity in renal cancer cells. Cancer Res. 2011:71:6208-19.

117. Lin KT, Yeh YM, Chuang CM, Yang SY, Chang JW, Sun SP, et al. Glucocorticoids mediate induction of microRNA-708 to suppress ovarian cancer metastasis through targeting Rap1B. Nat Commun. 2015;6:5917.

118. Li G, Yang F, Xu H, Yue Z, Fang X, Liu J. MicroRNA-708 is downregulated in hepatocellular carcinoma and suppresses tumor invasion and migration. Biomed Pharmacother. 2015;73:154-9.

119. Song T, Zhang X, Zhang L, Dong J, Cai W, Gao J, et al. miR-708 promotes the development of bladder carcinoma via direct repression of Caspase-2. J Cancer Res Clin Oncol. 2013;139:1189-98.

120. Jang JS, Jeon HS, Sun Z, Aubry MC, Tang H, Park CH, et al. Increased miR-708 expression in NSCLC and its association with poor survival in lung adenocarcinoma from never smokers. Clin Cancer Res. 2012:18:3658-67.

121. Maugeri M, Barbagallo D, Barbagallo C, Banelli B, Di Mauro S, Purrello F, et al. Altered expression of miRNAs and methylation of their promoters are correlated in neuroblastoma. Oncotarget. 2016;7(50):83330-41.

122. Wong KY, Yim RL, So CC, Jin DY, Liang R, Chim CS. Epigenetic inactivation of the MIR34B/C in multiple myeloma. Blood. 2011;118:5901-4.

123. Kumamoto K, Spillare EA, Fujita K, Horikawa I, Yamashita T, Appella E, et al Nutlin-3a activates p53 to both down-regulate inhibitor of growth 2 and up-regulate mir-34a, mir-34b, and mir-34c expression, and induce senescence. Cancer Res. 2008;68:3193-203.

124. Wang X, Lu X, Fang Y, Chen H, Deng X, Peng C, et al. Association between miR34b/c polymorphism rs4938723 and cancer risk: a meta-analysis of 11 studies including 6169 cases and 6337 controls. Med Sci Monit. 2014;20:1977-82.
125. Masecchia S, Coco S, Barla A, Verri A, Tonini GP. Genome instability model of metastatic neuroblastoma tumorigenesis by a dictionary learning algorithm. BMC Med Genet. 2015;8:57.

126. Toraman AD, Keser I, Luleci G, Tunali N, Gelen T. Comparative genomic hybridization in ganglioneuroblastomas. Cancer Genet Cytogenet. 2002;132:36-40.

127. Coco S, Defferrari R, Scaruffi P, Cavazzana A, Di Cristofano C, Longo L, et al. Genome analysis and gene expression profiling of neuroblastoma and ganglioneuroblastoma reveal differences between neuroblastic and Schwannian stromal cells. J Pathol. 2005;207:346-57.

128. Bourdeaut F, Ribeiro A, Paris R, Pierron G, Couturier J, Peuchmaur M, et al. In neuroblastic tumours, Schwann cells do not harbour the genetic alterations of neuroblasts but may nevertheless share the same clonal origin. Oncogene. 2008;27:3066-71

129. Ambros IM, Amann G, Ambros PF. Correspondence re: J. Mora et al., Neuroblastic and Schwannian stromal cells of neuroblastoma are derived from a tumoral progenitor cell. Cancer res., 61: 6892-6898, 2001. Cancer Res. 2002;62:2986-7. author reply 8-9

130. Ambros IM, Zellner A, Roald B, Amann G, Ladenstein R, Printz D, et al. Role of ploidy, chromosome 1p, and Schwann cells in the maturation of neuroblastoma. N Engl J Med. 1996;334:1505-11.

131. Mora J, Akram M, Cheung NK, Chen L, Gerald WL. Laser-capture microdissected schwannian and neuroblastic cells in stage 4 neuroblastomas have the same genetic alterations. Med Pediatr Oncol. 2000;35:534-7.

132. Mora J, Cheung NK, Juan G, Illei P, Cheung I, Akram M, et al. Neuroblastic and Schwannian stromal cells of neuroblastoma are derived from a tumoral progenitor cell. Cancer Res. 2001;61:6892-8.

133. Angelini P, Baruchel S, Marrano P, Irwin MS, Thorner PS. The neuroblastoma and ganglion components of nodular ganglioneuroblastoma are genetically similar: evidence against separate clonal origins. Mod Pathol. 2015;28:166-76.

134. Bosse KR, Maris JM. Advances in the translational genomics of neuroblastoma: from improving risk stratification and revealing novel biology to identifying actionable genomic alterations. Cancer. 2016:122:20-33.

\section{Submit your next manuscript to BioMed Central and we will help you at every step:}

- We accept pre-submission inquiries

- Our selector tool helps you to find the most relevant journal

- We provide round the clock customer support

- Convenient online submission

- Thorough peer review

- Inclusion in PubMed and all major indexing services

- Maximum visibility for your research

Submit your manuscript at www.biomedcentral.com/submit
Biomed Central 